LISANIA: Journal of Arabic Education and Literature

P-ISSN: 2614-4425 E-ISSN: 2580-1716

Vol.4, No.1, 2020, pp.23-36

DOI: http://dx.doi.org/10.18326/lisania.v4i1.23-36

\title{
Non-Arabic Languages in the Qur'an according to as-Suyuti, Ibn al-Subki and al-Khafiz Ibn Hajar
}

\author{
Murdiono \\ Universitas Muhammadiyah Malang \\ murdiono@umm.ac.id
}

\begin{abstract}
ENGLISH ABSTRACT
This research aims to describe non-Arabic languages in the Qur'an according to the scholars who agreed on mu'arrab namely as-Suyuti, Ibn al-Subki and al-Khafiz Ibn Hajar and to reveal the meaning of the word including ta'rîb in the Qur'an. It uses library research method and descriptive qualitative technique analysis with structural, historical, and ideological approaches for the data analysis technique. The results of the study show that: 1) Factors which influence the occurrence of ta'rîb in Arabic especially in the Qur'an are the historical factors, namely geographical proximity, trading relations, immigration, political power, religious tendencies, culture, economy, and industry with other nations. 2) Arabic grows and develops with its closest Semitic languages, such as Habsyah, Aramiah and Akadiah so it will indirectly lead into language and cultural shift. 3) In as-Suyuti madhzab, including Ibn alSubki, and al-Khafiz Ibn Hajar, believe in the existence of mu'arrab and ta'rîb in the Qur'an, so he collected around 125 non-Arabic words in the Qur'an which consists of 13 languages, including Persian, Habsyah, Hebrew, Suryaniyah, Nabathea, Berber, Zinjiyah, Jewish, Roman, Indian, Saizalah, Turkish and Magrib which are distributed in 41 surahs of the Qur'an.
\end{abstract}

Keywords: Non-Arabic Language, al-Qur'an Words, Scholars

\section{INDONESIAN ABSTRACT}

Penelitian ini bertujuan untuk mendeskripsikan bahasa-bahasa non-Arab di dalam alQur'an menurut para ulama yang sepakat adanya mu'arrab yaitu as-Suyuti, Ibn al-Subki dan al-Khafiz Ibn Hajar serta mengungkap makna kata yang termasuk ta'rîb di dalam alQur'an. Metode Penelitian yang digunakan adalah Penelitian kepustakaan (library research) dan teknik analisis data yang digunakan yaitu teknik analisis deskriptif kualitatif dengan pendekatan Strukturalis, Historis dan Idiologis. Adapun hasil penelitian menunjukkan bahwa: 1) Faktor yang mempengaruhi terjadinya ta'rîb dalam bahasa Arab khususnya di dalam al-Qur'an adalah faktor historis yaitu kedekatan letak geografis, hubungan perdagangan, imigrasi, kekuasaan politik, kecenderungan religius, kultur, ekonomi, indrustri, dengan bangsa-bangsa lain. 2) Bahasa Arab tumbuh dan berkembang dengan bahasa Semit terdekatnya, seperti bahasa Ibrani, bahasa Aramiah dan bahasa Akadiah sehingga secara tidak langsung akan terjadi pergeseran bahasa dan budaya. 3) Dalam madhzab as-Suyuti temasuk juga Ibn al-Subki dan al-Khafiz Ibn Hajar meyakini 
adanya mu'arrab dan ta'rîb di dalam al-Qur'an sehingga beliau mengumpulkan sekitar 125 kata non Arab di dalam al- Qur'an yang terdiri dari 13 bahasa di antaranya bahasa Persia, Habsyah, Ibrani, Suryaniyah, Nabathea, Berber, Zinjiyah, Yahudi, Romawi, India, Saizalah, Turki dan Magrib yang tersebar di 41 surat al-Qur'an.

Kata kunci: Bahasa Non-Arab, Kosakata al-Qur'an, Ulama

\section{Introduction}

In the Qur'an, there are ten verses that indicate the Qur'an is in Arabic, as in Surah Yusuf verse 2, al-Ra'd verse 39, al-Nahl verse 103, Thaha verse 113, al-Syu'ara' verse 195, al-Zumar verse 28, Fushshilat verse 44, al-Syura verse 7, al-Zukhruf verse 3 and al-Ahqaf verse 12 . The classical interpretations with the pattern of âtsâr like Jami' al-Bayân as well as the modern interpretation which provides more logical analysis such as Fīl Dhil alQur'ân and the interpretation of al-Manâr which translates the word "Arabiy" in these verses as "Speaking Arabic". Allah revealed the Qur'an to Rasulullah PBUH by speaking Arabic and no other languages (Harun: 1990).

In the history, before the revelation of Qur'an, there were many languages that people used to make contact with other nations such as Arabic, Hebrew (still in use), Iram (extinct), Habasyah (Ethiopia) (extinct), Berber (extinct), Qibti or Koptik (extinct in conversation and existed in ancient form), Persian (still in use), Indian (still in use), Latin (existed in writing and extinct in conversation) and Greek language is still in use today (Ballasy: 2011). Therefore, it does not rule out the possibility of many non-Arabic words in the Qur'an being Arabic (Arabization) or ta'rîb (As-Suyuty: 1987). This fact is also supported by the word of Allah the Almighty in surah Ibrahim verse 4:

"And we did not send any messenger, but the language of his people" (QS. Ibrahim: 4).

Wahyudin (2015) in his study stated that the discussion of whether there is a foreign language vocabulary in the Qur'an or not, is an important study because the legitimacy of the Quranic language is being questioned by many now, especially among orientalists. On the other hand, Al-Zamakhshari in his interpretation explains that Rasulullah PBUH was not only sent to the Arabs but also to the human race in general where the language is diverse. Saleh stated that since the time of ignorance (jahiliyah) or before the revelation of Quran, Arabic has experienced al-Ta'rîb or al-Iqtirâd. It can be seen in the poetry of ignorance (jahiliyah) era. After Islam came, the process of al-Ta'rîb 
or al-Iqtirâd was continued to grow so that the foreign vocabulary was not only found in the language of the poets but also used by the leaders, at home and in the market, and even in Quran and Hadith, if it was observed further, foreign vocabularies will be found.

In Arabic context, as the language of the Quran, it does not stand alone but mutually influencing and absorbing from other foreign languages which are usually associated with al-ta'rîb (Hammam: 2017). The new vocabulary appeared in Arabic is closely related to the role and position of other languages towards Arabic (Amrulloh and Himmah: 2017). Thus, indirectly, this phenomenon indicates that language, wherever it may be, is also evolving along with its users (Malik: 2009).

Maimun (2010) in his thesis explained that language contact is a process of mutual influence between one language with another language, both at the difference of language level and/or dialect level. These influences result in the change or absorption of language elements. Likewise, Yuspa in his research explained that the interaction between nations in the world caused a contact between languages which could cause positive or negative influence on each other. So there are languages that dominate other languages very much and some eventually die without speakers, or are forced to adopt some of the words or grammar from other languages.

Abdurochman (2016) in his research stated that Arabic is the most important language, the most extensive scope and the best language, because the language is used since the prophet Adam AS. Hence, it is very interesting to be studied. Arif (2017) also explained that Arabic as living language that is able to maintain its own continuity and development. As the language of Qur'an, Arabic has maintained its survival along with the development of Islam.

Since its emergence till now, Arabic has experienced a lot of changes in terms of language style in the acquisition of new vocabularies due to the language acquisition process is by absorbing foreign words (Ubaidillah, 2013: 1). This process is a normal and natural thing. Likewise, Arabic naturally influences and is influenced by other languages as explained above.

Consequently, there are different opinions emerged and a long debate by the scholars regarding the presence or absence of the absorption words in the Qur'an (ta'rîb). Some disagree with the existence of non-Arabic words in the Qur'an and there are those who agree with that. Among the scholars who argue that there are non-Arabic words in 
the Qur'an are as-Suyuti, Ibn al-Subki and al-Khafiz Ibn Hajar. Although the Qur'an is written in Arabic, some of its vocabularies are believed to be originated from absorbed languages. For this reason, this research will discuss the non-Arabic languages in the Qur'an according to scholars who agreed to mu'arrab, namely as-Suyuti, Ibn al-Subki and al-Khafiz Ibn Hajar.

\section{Research Methodology}

The researcher uses qualitative research, which is a type of research that produces findings that are not obtained using quantification method. It can lead to research on nonArabic languages in the Qur'an and the opinions of the scholars regarding these words (Rulam: 2006). The data resources used here are the primary and secondary data resources. The primary data source is the non-Arabic vocabularies in the Qur'an. The secondary data is the data obtained through other parties, not directly obtained by the researcher. In this case, the secondary data sources are al-Muhadhdhab fî mâ wâqa'a fî alQur'ân min al-Mu'arrab " by al-Imam Jalaluddin as-Suyuty," al-Lughat fî al-Qur'ân " by Ismail bin Umar, and "al-Mu'arrab fî al-Qur'ân al-Karîm" by Muhammad Sayyid ali Ballasy.

The data analysis process is started by examining the data available, the Qur'an. The process is by reading and collecting data. After reading, studying, and analyzing, the next step is conducting data reduction by making abstraction. The next step is arranging the data unit in chapters that correspond the logical reasoning order.

The first step in interpreting data is to find categories and its regions. Data is interpreted into a category which means it has become part of the theory and is complemented by arranging the hypotheses as a theory which will be formulated, both descriptively and proportionally. The categories and relationships are labeled with a simple statement in the form of proportions (draft proposal) which presents the relationship. This process is continued until an adequate relationship is obtained, that is, until the metaphor clues or the general thinking framework analysis were found.

This relationship serves as a fixed rule used as an inclusion-exclusion criterion. After completing the stages of arranging categories and hypotheses, the next step is writing the theory in the language of each disciplines by choosing one of several ways of writing. The writing types used here are argumentative, descriptive, comparative, process analysis, cause effect analysis and analogy. To help, ease, deepen and enrich the text 
understanding, it requires several approaches, namely structuralist approach, historical approach, and ideological approach.

The structuralist approach (bunyawiyyah) is studying the non-Arabic languages in the Qur'an as a totality, supported by the researchers' reasoning who dwell on the same point. Basically, the researcher's thoughts must be focused on the main problem, able to accept various forms of transformation as a way for the researcher's logical reasoning process, so that all of his ideas have a natural place in its totality.

The historical approach (târikhiyyah) is done by attempting the association of nonArabic words in the Qur'an with the cultural, political, ideological and social historicity of the past. Involving this context is a necessity, not only to get a historical understanding of what is being studied but also to test the validity of the structuralist model.

The last is ideological approach, it means renewing the ideological function which contains the "Arabization of non-Arabic languages in the Qur'an" by filling in the cognitive field as part of the research. The third approach serves as a complement to the two approaches before.

Non-Arabic Languages in the Qur'an according to as-Suyuti, Ibn al-Subki and alKhafiz Ibn Hajar

After an in-depth study on as-Suyuti, Ibn al-Subki and al-Khafiz Ibn Hajar opinions related to the non-Arabic languages in the Qur'an, the researcher found 125 words spread in 41 surahs consisting of 13 languages that were explained into two discussions namely the rules for understanding ta'rib according to the scholars and understanding ta'rib and its meanings in the Qur'an according to the alphabet as follows:

\section{Rule for Understanding Non Arabic Words (Ta'rîb)}

The Arabic scholars made a specific language principle to determine that a word was included in Arabic or Non-Arabic. The principle is divided into two, namely Arabic letters that cannot be gathered in one sentence and letters that can be gathered in one sentence. These provisions are based on the Arabic traditions of the Arabs, as outlined in the following 2 tables:

Table 1. Arabic Letters that Cannot Gather in One Sentence

\begin{tabular}{llll}
\hline No & Letter & Example & Explanation \\
\hline 1 & الجيم and الجوق الجئ & Cannot be in one sentence \\
\hline
\end{tabular}




\begin{tabular}{|c|c|c|c|}
\hline 2 & الجيم and الصاد & صولجان & Cannot be in one sentence \\
\hline 3 & التاء and الطاء & 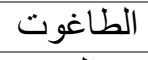 & Cannot be in one sentence \\
\hline 4 & التاء and الجيم & 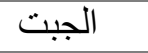 & Cannot be in one sentence \\
\hline 5 & الطاء and الصـاد & الصر اط اط & Cannot be in one sentence \\
\hline 6 & السين and الباء & سلسبيل & Cannot be in one sentence \\
\hline 7 & الذال and السين & أستاذ & Cannot be in one sentence \\
\hline
\end{tabular}

Table 2. Letters Collected in One Sentence Which are Not Included in Arabic Tradition

\begin{tabular}{|c|c|c|c|}
\hline No & Letter & Example & Explanation \\
\hline 1 & الر اء before النون & نرجس & Not included as original Arabic \\
\hline 2 & الدال after الزاء & مهندز & Not included as original Arabic \\
\hline 3 & اللام after الثين Letter & & Not included as original Arabic \\
\hline 4 & الدال after الذال & & Not included as original Arabic \\
\hline
\end{tabular}

\section{Non Arabic Languages and Their Meanings in The Qur'an}

Arabic never stops assimilating words of other languages, such as Hindi, Persian, Greek, Syrian, and others. The result is its linguistic heritage has rich scientific side, in turn, it enriches the Arabic language to face modern Arabization process in its broadest sense (Abdul Aziz: 2019). Languages are currently undergoing rapid development, which has led to the emergence of many new terms in the western world that influence one language and another, one of which is Arabic (Asmara: 2019).

Imam Al-Suyuti, in addition to his own opinion, also included the opinions of other scholars such as Ibn al-Subki and al-Khafiz Ibn Hajar compiling non-Arabic vocabulary used in the Quran:

\section{Hamzah (الههزة)}

The word أباريقin Surah al-Waqi'ah verse 18. The word أباريق in the verse comes from Persian language which means water channel or pouring water. The word الحس in surah Abasa verse 31 which means (grass) is ahlu al-Maghrib language (al-Suyuti). The word إبلعى in surah Hud verse 44, in his interpretation (Ibn Abi Hatim: 2004), as quoted by Imam al-Suyuthi states that the word إبلعى is derived from the Habsyi language. Meanwhile Saikh bin Hayyan states that the word was from Hindi. The word أخلد in the surah al-A'raf verse 176 which means ركون (backup) is from Hebrew. 
The word ألأر ائك in surah al-Kahfi verse 31 according to Ibn al-Jauzi in his book Funun al-Afnan (Ibn jauzi: 1987) as quoted by al-Suyuti states that the word is in Habsi language which means couch or bed. The word آزر in surah al-An'am verse 84 according to al-Kirmaniy in the book "al-Ajâ'ib", as quoted by al-Suyuthi الثيخ in the verse comes from Persian which means آزر (elderly). The word إستبرق in surah ar-Rahman verse 54, according to Abu Hatim and Abu Ubaid, as quoted by al-Suyuthi, it is believed that the word came from Persian language (al-Faraji: 1987).

The word أسفر in surah al-Mudatsir's verse 34 according to al-Wasth in the book "al-Irsyâd" states that the word أَسْفَرَ in the verse is from Suryani language, while al-Kirmaniy thinks that the word is from Nabti language. The word either in Suryani or Nabti, means the same as الكتب (book). The word إصرى in surah Ali-Imran verse 81 according to Abu al-Qasim in his book "Lughât al-Quran" (alQasim: 1956) states that the word إصرى in the verse comes from Nabti language which means عهد (covenant). The word أكواب in surah al-Waqi'ah verse 18 comes from Nabti language which means glass or cup.

إل أليم in surah al-Baqarah verse 10 comes from Hebrew. The word in surah as-Shaffat verse 130 comes from Nabti language which is the name of Allah. The word إناه in surah al-Ahzab verse 53, according to Abu Qasim it comes from the Barbarian language. The word أنية in surah al-Ghasyiyah verse 5 comes from Barbarian which means حارة in Barbarian. The word أو in surah Hud verse 75 comes from Habsyi language. The word أو اب in the surah as-shad verse 17 is derived from Habsyi language which means أوبى المصباح. The word comes from Habsyi. The word الإخرة in surah al-Ahzab verse 33 comes from Habsyi language. As stated by al-Zarkasyi in al-Burhan, where Nabti people named al-Akhirah with al-Ûla and alÛla with al-Akhirah. The word الأولى in surah as-Shad verse 7 comes from Habsyi language.

\section{Ba '(الباء)}

The word بطائنها in surah ar-Rahman verse 54 means "the inner part of silk". The word comes from Qibthi language. The word بعير in surah Yusuf verse 65 which means "the weight of a camel" in the verse is in Hebrew. The word بيع in surah alBaqarah verse 254, the word بيع which means "trading" is from Persian. 


\section{Ta '(التاء)}

The word تنور in surah Hud verse 44 and al-Mu'minun verse 27 which means "bakery" comes from Persian language. The word In surah al-Isra verse 7 and surah al-Furqan verse 39 which means "to destroy it completely" in both verses is from the Nabathea (Nabti) language. The word تحت in surah Maryam verse 24 which means "stomach" in the verse comes from Nabathea language.

\section{Jim (الجيم)}

The word الجبت in surah an-Nisa verse 51 which means "a name of idols" is derived from Habasyah language.

\section{Ha (الحاء)}

The word حرم in surah al-Baqarah verse 173 which means "obligatory" is from Habasyah language. The word حصب in surah al-anbiya verse 89 which means "fuel" comes from the Zinjiyah or Zanjiy language. The word حطة in surah alBaqarah verse 58 and al-A'raf verse 161, meaning "free from sin" is Lafaz-lafaz of scholars who do not know the meaning clearly, but in the Qur'an it is interpreted as "release us from our sins." The word حواريون in surah al Imran verse 52, al Maidah verse 112, and ash Shaf verse 14 is translated as "Faithful companions." In the three verses the word حواريون comes from Nabathea or Nabthi language, and the word حوب in surah an-Nisa verse 2 is translated as "إنث" (sin) is derived from Habasyah language.

\section{Dal (الدال)}

The word دري in surah an-Nur verse 35 is translated as "luminous" comes from Habasyah language. The word دينار in surah Ali-Imran verse 75 which is translated as "gold coin" is Persian.

\section{Ra' (الراء)}

The word ر اعنا in surah al-Baqarah verse 104 and surah an-Nisa verse 46 is interpreted as "defamatory" derived from Jewish language. The words ربانيون in surah al-Maidah verse 44 and verse 63 are interpreted by "their priests" in fact, only scholars who know the meaning. The language is from Suryaniyah or Suryani. The word الرحمن is found in surah ar-Rahman verse 1 which means "loving" comes from Hebrew language. The word الرس in surah Qof verse 12 and 14 and is interpreted as البئر (Well) derived from the A'jami language. The word الرقيم in surah 
al-Kahfi verse 9 which means "ink" comes from Roman language. The word رمزا in surah Ali-Imran verse 41 which means "moving both lips" comes from Hebrew language. The word رهو In surah ad-Dukhan verse 24 which means "split" comes from Suryaniyah language. Abu Qasim in his book "Lughât al-Qur'an" states that the word is derived from Nabti language which means سهلا, while al-Wasiti thinks it comes from Suryani language which means سكنا The word الروم in surah ar-Rum verse 2 means "the name of (one) mankind generation" is derived from A'jami language (non-Arabic).

\section{Za (الزاء)}

The word زنجبيل is found in surah ad-Dakhar verse 17 which means "ginger" is from Persian language.

\section{Sin (السين)}

The word السجل in surah al-Anbiya verse 104 which means "a man" is derived from Habasyah language. There are several opinions on the origin of the word سجل Some say that the word is from Abysinia and it means رجل (man). While Ibn Jinni translates it as "letter" and he thinks the word is from Parsi. Khaffaji agrees with the opinion that this word is from Abysinia and means "letter." Arthur Jeffery rejected these two opinions and stated that the word was not from Abysinia nor from Persia, but rather from Greek equivalent of Latin word "sigillum."

The wordis in surah al-Muthafifin which means "hell" derived from foreign languages. Abu Hatim explained that the word was not in Arabic. The word in surah Abasa verse 15 which means "readers" derived from Nabathea or Nabti language. The word سري is found in surah Maryam verse 24 which means "river" comes from Nabti or A'jamiy. The word سكر in surah an-Nahl verse 67 which is translated as "vinegar" is derived from Habasyah. The word سلسبيل in surah adDahr verse 18 which means "spring" is derived from A'jami language. The word in surah an-Nur verse 43 which means "light" comes from A'jami language. The word wندس in surah al-Kahfi verse 31 which means "thin silk" is derived from Indian language. The word سيده in surah Yusuf verse 25 which means "husband" comes from Qibthi language. The word سنين in surah Yusuf verse 42 means "beauty" the word is derived from Habasyah. The word سيناء in surah al-Mu'minun verse 20 which means "good" comes from the Nabathea language. 


\section{Shin (الثين)}

The word شطر in surah al-baqarah verse 144, 149 and 150 which means as "towards" is derived from Habasyah. The word شهر in surah al baqarah verse 185 means "the moon" comes from Suryani language.

\section{Shad (الصاد)}

The word الصراط in surah al Fatihah verse 6 is translated as "road" comes from Roman language. The word صر هن in surah al baqarah verse 260 is translated as "cut" comes from Nabathea language. The word صلوات in surah al baqarah verse 157 is translated as "Jewish monastery" derived from Hebrew language.

\section{Tha (الطاء)}

The word الطاغوت in surah al-baqarah verse 257 which means "shaman" is derived from Habasyah language. The word طا طه contained in surah Thaha verse 1 is derived from Habasyah language. The word طفقا is found in surah Shad verse 33 which means "they both want" derived from Saizalah language. The word طوبى in surah ar-Ra'd verse 29 which means "return" comes from Indian language. The word طور in surah al-Mu'minun's verse 20 means "mountain" comes from Suryani language. The word طوى is found in surah Thaha verse 12 is translated as "رجل in Hebrew.

\section{Ain (العين)}

The word عبدت is found in surah as-Syu'ara verse 22 which means "enslave the children of Israel" comes from Nabathea language. The word عدن is found in surah at-Taubah verse 72 which means "vineyards" comes from Suryani language. The word العرم is found in surah as-Saba verse 16 which means "dam that holds a lot of water and then explodes" comes from Habasyah language.

\section{Ghain (الغين)}

The word غساقin surah Shad verse 57, means "cold and foul" comes from Turkish. The word غيض in surah Ali-Imran verse 134 which means "anger" is derived from Habasyah language.

\section{Fa (الفاء)}

The word فردوس in surah al-kahfi verse 107 which means "vineyard" comes from Roman and Nabathea languages. The word فوم in surah al-Baqarah's verse 61 which means "wheat" comes from Ibriah language. The word قراطس in surah al- 
An'am verses 7 and 91 comes from foreign languages and from Greek word "charta". Whereas in Abysinia, it is "kartas". As as-Suyuti commented on the statement the word قرطاس , th not Arabic.

The word قسط in surah Ali-Imran verse 18 comes from Roman word which means "justice". The word قسطاس in surah al-Isra verse 35 from Roman word means "scales" (As-Suyuty). The wordة قصورة in surah al-Furqan's verse 10 is from Habasyah which means "lion". The word قطنا in surah Shad verse 16 is derived from Nabathea language which means "our book". The word قفل in surah Muhammad verse 24 means "key". The language is derived from Ibri or Suryani. Meanwhile, Abu Umar, when he was asked about the vocabulary, expressed his incomprehension about the origin of the vocabulary.

The word قنطار in surah an-Nisa verse 20 means "twelve thousand auqiyah". There are many opinions on the origin of the word, at least four different views cited by al-Suyuti; Tha'âlabi claimed that the word was originally from Roman, alKhalil claimed it was from Suryani, ibn Qutaibah claimed it was from Africa, while others stated it was from Barbarian language. The word القيو in surah al-Baqarah's verse 255 which means "not sleeping" comes from Suryani language.

\section{Kaf (الكاف)}

The word كافور in surah al-Insan verse 5 which means "camphor" comes from Persian. Whereas in Indonesian, it means "chalk." The word كفر in surah alImran verse 193 which means "remove (it) from us" is from Nabathea language and there is also a history that says it came from Hebrew language. The word كفلين in surah al-Hadid verse 28 which means "twice" is derived from Habasyah language. The word كنز in surah Hud verse 12 which means "assembly" is in Persian. The word كورت in surah at-Takwir verse 1 which means "rolled" comes from Persian.

\section{Mim (الميم)}

The word متكاء in surah Yusuf verse 31 which means "stumbling" comes from Habsyah language. The word مجوس in surah al-Haj verse 17 which means "Majusi people" is included as Foreign language. The word مرجان in surah arRahman verse 22 means "sea coral" is also included as Foreign language. The word in surah an-Nur verse 3 which means "lantern" is in Habasyah language. The 
word مقالبد in surah az-Zumar verse 63 which means "keys" is in Persian. The word in surah al-Muthafifin verses 9 and 20 which means "written" is in Hebrew. The word مزجات in surah Yusuf verse 88 which means "Little/few" is in Qibti language. The word ملكوتin surah al-Mu'minun verse 88 which means "kingdom" is Nabathea language.

The word مناصin surah Shad verse 3 which means "place of escape" is Nabathea language. The word منشاءة in surah al-Rahman verse 34 which means "sailing" is Habasyah language. The word منفطر in surah al-Muzzamil's verse 18 which means "full" is in Habasyah language. The word st in surah al-Kahfi's verse 29 means "wave" is Barber language.

\section{Nun (النون)}

The word ناثشئة in surah al-Muzammil verse 6 which means "wake up at midnight" is Barber language.

\section{Ha (الهاء)}

The word هدنا in surah al-A'raf verse 156 which means "we repent" is included in Hebrew language. The word هود in surah Hud verse 53 which means "Jews" is in Hebrew language. The word هون in surah al-Furqan's verse 63 which means "humble" is in Suryani language. The word هيت in surah Yusuf verse 23 which means "come here" is in Qibthi language.

\section{Waw' (الواو)}

The word وراء in surah al-Baqarah verse 10 which means "behind" is included in Nabathea language. The word وردة in surah ar-Rahman verse 37 is also a foreign language. The word وزر in surah an-An'am verse 164 which means "to shield/shelter" is Nabathea language.

\section{Ya' (الياء)}

The word ياقوت Persian. The word يس in surah Yasin verse 1 which means "O people" includes in Habasyah language. The word بصدون in surah an-Nisa verse 61 which means "to make a noise" is in Habasyah. The word يص in surah al-Haj verse 60 which means "mature" is in Maghrib language. The word يحور in surah al-Insyiqaq's verse 14 which means "back" is in Persian. 


\section{Conclusion}

Ta'rîb is a non-Arabic language used by Arabs as a language. There are two language rules specifically for Arabic or Non Arabic languages, namely Arabic letters which cannot be combined in one sentence (letter الجيم and الجيم and الصاد letter, letter

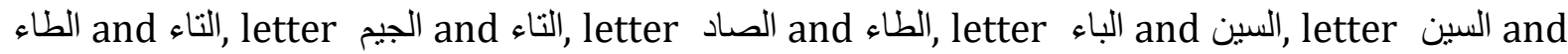

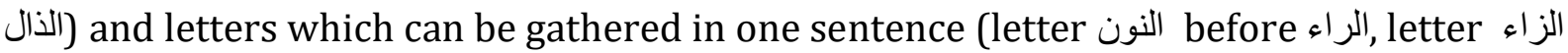
after الثين after اللام after الذال and letter lالدال). This provision is based on the Arab tradition. Imam al-Suyuti, and other scholars' opinions such as Ibn al-Subki and al-Khafiz Ibn Hajar collected about 125 non-Arabic words in the Qur'an consisting of 13 Languages, they are: Persian, Habsyah, Hebrew, Suryaniyah, Nabathea, Berber, Zinjiyah, Jewish, Roman, Indian, Saizalah, Turkey, and Maghrib which are distributed in 41 surahs of the qur'an.

\section{References}

Abdul Aziz. "Ta'rib Dan Semangat Nasionalisme Kebahasaan Arab". Jurnal Kajian Ilmu dan Budaya Islam, vol.2, no. 1, 2019, pp. 49-58. DOI: https://doi.org/10.36670/alamin.v2i1.15.

Abdurochman. "Bahasa Arab: Keistimewaan, Urgensi Dan Hukum Mempelajarinya." Jurnal Al Bayan: Jurnal Jurusan Pendidikan Bahasa Arab, vol. 8, no. 2, 2016, pp. 1-15, doi:10.24042/albayan.v8i2.361.

Abi al-Faraji Abdirrahman Ibnu jauzi. Funuunul Afnan Fii Ayuunu Ulumul Qur'an. Daarul basyair al-Islamiyah, 1987, p. Cetakan pertama.

Abu al-Qasim. Lughah Fil Qur'an. 1946, p. 47.

Al-Zamakhshari. Al-Kasyaf an-Haqa'iq Al-Tanzil Wa 'Uyun Al-'Aqawil Fi. Dar al-Fikr, 1977, p. Vol. 4.

Amrulloh, Muhammad Afif, and Ro'fat Hizmatul Himmah. "Analisis Perubahan Morfologis Pembentukan Ta'rib Dan Pembelajaran." Tadris: Jurnal Keguruan Dan Ilmu Tarbiyah, vol. 2, no. 2, 2017, p. 87, doi:10.24042/tadris.v2i2.2064.

Arif, Muh. "Bahasa Arab Di Indonesia." Journal of Chemical Information and Modeling, vol. 53, no. 9, 2017, pp. 1689-99, doi:10.1017/CB09781107415324.004.

As-Suyuty. Al-Itqan Fii Ulumil Qur'an. 1987, p. 193.

Asmara, Hilda Dimyati. “Arabisasi (Ta'rib) Istilah-Istilah Ilmiah Dalam Buku Pelajaran Biologi Kelas 3 SMA." Alfaz (Arabic Literatures for Academic Zealots), vol. 7, no. 02, 2019, p. 87, doi:10.32678/alfaz.vol7.iss02.2290. 
Hammam. "Analisis Kata Serapan Bahasa Asing Dalam Al Quran Perspektif Imam Suyuthi." Journal of Chemical Information and Modeling, vol. 53, no. 9, 2017, pp. 1689-99, doi:10.1017/CB09781107415324.004.

Harun, Salman. Mutiara Al-Quran. PT. Logos Wacana Ilmu, 1990.

Ibnu Abi Hatim. "Tafsir Ibnu Abi Hatim Ibnu." Current Topics in Microbiology and Immunology, vol. jilid 12, 2004, pp. 99-119, https://lib.unnes.ac.id/17153/1/1201408017.pdf.

Jalaluddin 'Abdurrahman al-Suyuti. Al-Muhadhdhabu Fima Waqa'a Fi AlQur'an Min AlMu'arrab. pp. 1-48.

Maimun, Muhammad. Kosakata Asing Dalam Al-Qur' an. 2010.

Malik, Abdul. "Arabisasi (Ta'Ri B) Dalam Bahasa Arab (Tinjauan Deskriptif-Historis)." Adabiyyāt: Jurnal Bahasa Dan Sastra, vol. 8, no. 2, 2009, p. 261, doi:10.14421/ajbs.2009.08204.

Muhammad asayyid ali Ballasy. Al Muarrab Fil Qur'an Dirasah Ta;Siliyah Dalaliyah. darul kutub, 2011.

Rulam Ahmadi. Metodologi Penelitian Kualitatif,. no. November, 2006, pp. 1-21.

Saleh, Subhi. Dirāsāt Fi Fiqh Al-Lughah. Dār al-Ilm alMalāyīn, 1968.

Ubaidillah, Ismail. "Kata Serapan Bahasa Asing Dalam Al-Qur'an Dalam Pemikiran AtThobari." Jurnal At-Ta'dib, vol. 8, no. 1, 2013, pp. 119-32.

Wahyudin. Pandangan Para Ahli Bahasa Tentang Bahasa Serapan Dalam Al-Quran. 2015, doi:10.18196/AIIJIS.2015.

Yuspa, Anida. "Arabisasi Kata-Kata Asing Sebagai Usaha Mempertahankan Gramatika Dan Morfologi Bahasa Arab". Jurnal al-Fathin, vol.1, no.1, 2018

Zuhriah. "Eksistensi Kata Serapan Dalam Al-Qur'an".Jurnal Ilmu Budaya, vol 4, no.1 2016, pp. 64-71. 